Gill, S. 1994. Take control with Bio-control. part 1. Greenhouse Grower 12(2):20, 22-24.

Heinz, K.M. and M.P. Parrella. 1993. Have you though about biological whitefly control?: Pesticidealternatives can saveyou money. Greenhouse Manager (Aug.):62, 64-66, 69.

Hodges, A. 1991. Business analysis of woody ornamental container and field nurseries in Florida, 1989. Fla. Coop. Ext. Serv. IFAS Circ. 954.

Hodges, A. and D. Hull. 1991. Business analysis of foliageplant nurseries in Central and South Florida, 1989. Florida Coop. Ext. Serv. IFAS Circ. 953.

Lawson, R.H. 1994. Silicon reduces Pythium losses. Greenhouse Manager 13(1):81-82.

Moody, J.T. and M.C. Halbrooks. 1992. An integrated pest management extension program for nursery producers in South Carolina. S. Nursery Dig. 26(9):29-30.

Oetting, R.D. 1994. IGRs for IPM. Greenhouse Grower 12(12):28-31.

Onofrey, D. 1994. Environmental controls leave fungi dry. Greenhouse Grower 12(13):32-33, 36.

Parrella, M.P. 1994. The future of pesticides in floriculture. GrowerTalks 57(10):21, 23, 25, 27, $29,31$.

Robb, K. 1994. Try new earth-friendly controls. Greenhouse Manager 13(1):77, 79-80.

Whitten, M. 1994. Profits could sink with no alternative to methyl bromide. Greenhouse Manager 12(12):90, 92-95.
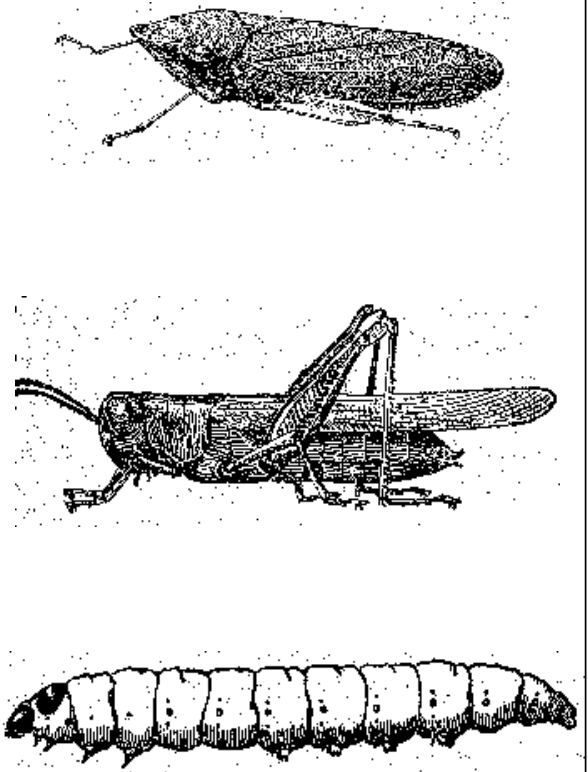

\section{Pest Management in the United States Greenhouse and Nursery Industry: II. Disease Control}

Ronald K. Jones ${ }^{1}$,
Ann R. Chase
Melvin P. Garber
,
William G. Hudson
,
Jeffrey G. Norcini ${ }^{5}$, and
Kane Bondari

Additional index words. fungicides, diseases, pesticides, biological control, alternative control, bactericides

Summary. A national survey of the commercial ornamental industry was conducted to determine the current status of pest control including chemical and nonchemical disease control practices. The fungicides thiophanate methyl, chlorothalonil, mancozeb, and metalaxyl were used in the greatest quantity and by

${ }^{1}$ Associate professor and extension plant pathologist, North Carolina State University, 2422 Gardner Hall, Raleigh, NC 27695-7616.

${ }^{2} E$ meritus professor of plant pathology, Central Florida Research and Education Center, University of Florida, Apopka, FL 32703.

${ }^{3}$ Associate professor and extension horticulturist, University of Georgia, P.O. Box 1209, Tifton, GA 31793

${ }^{4}$ Associate professor and extension entomologist, University of Georgia, P.O. Box 1209, Tifton, GA 31793

${ }^{5}$ Associate professor, University of Florida Research and Education Center, Route 4, Box 4092, Monticello, FL 32344-9304.

${ }^{6}$ Professor, Department of Statistical and Computer Service, Coastal Plain Experiment Station, Tifton GA 31793

The cost of publishing this paper was defrayed in part by the payment of page charges. Under postal regulations, this paper therefore must be hereby marked advertisement solely to indicate this fact. the largest percentage of growers.

Metalaxyl was used in greenhouse and field operations by the highest percentage of growers, primarily to control root diseases but many growers reported using metalaxyl to control foliar disease. Overall, more fungicides were used in the field for foliar diseases, whereas almost equal amounts of fungicides were used for foliar and root diseases in the greenhouse.

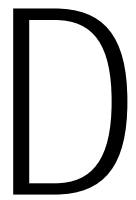

isease control methods have changed periodically over the years according to sociological and scientific developments. In the early 1900s, the ornamentals industry used many disease control methods based on cultural controls such as use of pathogen-free planting material (Murashige, 1974; Priapi, 1993), environmental manipulation, and a fewinorganic pesticides such as sulfur and copper used alone or in combination with lime to control diseases. During the 1960s, many new organic fungicides became available, which revolutionized disease control in the ornamentals industry. These fungicides were highly effective, active against a relatively narrow range of pathogens with low injury to crop plants, and easier to apply than previously available products. The use of these newer fungicides allowed higher-quality, lessexpensive plants to be distributed throughout the world.

During the past 10 years, improved environmental management techniques (Cuny, 1995) such as humidity control (Bartok, 1990; Onofrey, 1994), and light and temperature controls, especially with computerized systems (Pritchard and Flynn, 1993), have altered further the balance of pest control methods in the ornamental industry. Fungicide use patterns have continued to change during the past 5 to 10 years. Decreased, threatened or lost avail ability of standard industry chemicals such as methyl bromide (Whitten, 1994) dodemorph acetate and benomyl sometimes have forced a shift to less effective products or to nonchemical methods of pest control. New earthfriendly (Robb, 1994) products, such as silicon for Pythium control (Lawson, 1994), bicarbonates for powdery mildew control (Horst et al., 1992), horticultural oils (Steward, 1993), biorational (Triact) ,and biological (SoilGard) products (W.R. Grace\& Co., Grace BioControl, Columbia, Md.) currently are being researched and are labeled for use in the United States. At the same time, the industry has been confronted with pest resistance to some of the most commonly used products (Pommer and Lorenz, 1982; Roberts, 1994). Environmental regulations and USEPA Worker Protection Standards, such as reentry restrictions, have complicated further the use of pesticides on ornamentals. Finally, a dramatic shift in public opinion regarding 
Table 1. Estimated fungicide use in the United States.

\begin{tabular}{|c|c|c|c|c|}
\hline \multirow[b]{2}{*}{ Fungicide } & \multicolumn{2}{|c|}{ Respondents } & \multicolumn{2}{|c|}{ Amount (lb) } \\
\hline & No. & $\%^{2}$ & Estimated total active ingredient $\mathrm{y}$ & $\%$ \\
\hline Thiophanate methyl & 316 & 45 & 470926 & 31 \\
\hline Chlorothalonil & 225 & 32 & 285170 & 19 \\
\hline Mancozeb & 197 & 28 & 194106 & 13 \\
\hline Metalaxyl & 330 & 47 & 102150 & 7 \\
\hline Captan & 159 & 23 & 86315 & 6 \\
\hline Fosetyl Al & 187 & 27 & 74362 & 5 \\
\hline Iprodione & 165 & 24 & 70119 & 5 \\
\hline Copper & 157 & 22 & 66469 & 4 \\
\hline Propiconazole & 59 & 8 & 36070 & 2 \\
\hline PCNB & 84 & 12 & 34478 & 2 \\
\hline Triforine & 78 & 11 & 29413 & 2 \\
\hline Etridiazole & 90 & 13 & 28842 & 2 \\
\hline Vinclozolin & 87 & 12 & 17879 & 1 \\
\hline Triadimefon & 133 & 19 & 4714 & $<1$ \\
\hline Ferbam & 28 & 4 & 4670 & $<1$ \\
\hline Fenarimol & 47 & 7 & 2913 & $<1$ \\
\hline Triflumizole & 14 & 2 & 611 & $<1$ \\
\hline Ziram & 8 & 1 & 518 & $<1$ \\
\hline Other $^{x}$ & 64 & 9 & 19363 & 1 \\
\hline Total & 2431 & & 1533524 & 100 \\
\hline
\end{tabular}

${ }^{2}$ Determined by dividing number of users for each chemical by number of respondents from the respective region.

yUse for respondents expanded to total estimated use using USDA total sales for greenhouse/nursery industry; ratio of respondent sales to USDA sales used to estimate total use. xIncludes Agribrom, AMCL, benomyl, dinocap, dodemorph, dodine, myclobutranil, oxycarbofuran, phaltan, piperalic acid, steptomycin, and sulfur.

pesticide use has forced all segments of the agricultural industry to rethink the emphasis placed on chemical disease control (Blaine, 1993; Klassen, 1992; Pardo, 1995).

As scientists and educators, we have been waiting expectantly for commercial ornamental producers to rediscover methods of disease control based in nonchemical methodology (Onofrey,
1994). Recently, monthly columnsingrower magazines have been filled with articles extolling the benefits of integrated approaches to disease control (Barnes, 1993, 1994), and annual grower meetings sponsored throughout the United States by the Society of American Florists have focused on integrated pest management (IPM). The need for pathogen-free planting stock has been gaining followers (Priapi, 1993), as have the benefits of a well-ventilated greenhouse for pest and pathogen control (Kelly, 1994). Screening greenhouses to exclude insects, particularly virus vectors, has been gaining acceptance (J.R. Baker, personal communication).

The results of a national survey are presented herein to provide information for targeting

Table 2. Type of diseases controlled by fungicides in the United States greenhouse and nursery industry.

\begin{tabular}{|c|c|c|c|c|c|c|c|c|}
\hline \multirow[b]{3}{*}{ Fungicide/bactericide } & \multicolumn{4}{|c|}{ Field use } & \multicolumn{4}{|c|}{ Greenhouse use } \\
\hline & \multicolumn{2}{|c|}{ Foliar disease } & \multicolumn{2}{|c|}{ Root disease } & \multicolumn{2}{|c|}{ Foliar disease } & \multicolumn{2}{|c|}{ Root disease } \\
\hline & $\begin{array}{c}\text { No. } \\
\text { respondents }\end{array}$ & $\begin{array}{c}\text { Amount } \\
\text { a.i. }\end{array}$ & $\begin{array}{c}\text { No. } \\
\text { respondents }\end{array}$ & $\begin{array}{c}\text { Amount } \\
\text { a.i. }\end{array}$ & $\begin{array}{c}\text { No. } \\
\text { respondents }\end{array}$ & $\begin{array}{c}\text { Amount } \\
\text { a.i. }\end{array}$ & $\begin{array}{c}\text { No. } \\
\text { respondents }\end{array}$ & $\begin{array}{c}\text { Amount } \\
\text { a.i. }\end{array}$ \\
\hline Thiophanate methyl & 131 & 52499 & 45 & 9912 & 142 & 36429 & 147 & 28249 \\
\hline Chlorothalonil & 145 & 62053 & 10 & 1765 & 113 & 12209 & 12 & 321 \\
\hline Mancozeb & 109 & 40520 & 5 & 97 & 72 & 7911 & 2 & 2 \\
\hline Metalaxyl & 40 & 1667 & 158 & 13922 & 51 & 2334 & 202 & 12783 \\
\hline Captan & 85 & 3366 & 25 & 302 & 55 & 753 & 45 & 16630 \\
\hline Fosetyl al & 62 & 3175 & 102 & 11653 & 54 & 2235 & 69 & 2308 \\
\hline Iprodione & 63 & 7582 & 21 & 2158 & 116 & 10901 & 54 & 7432 \\
\hline Copper & 106 & 15310 & 8 & 17 & 66 & 1175 & 5 & 60 \\
\hline Propiconazole & 20 & 9759 & 4 & 87 & 11 & 380 & 2 & 1 \\
\hline PCNB & 10 & 563 & 28 & 6391 & 8 & 26 & 51 & 2336 \\
\hline Triforine & 49 & 4755 & 5 & 28 & 35 & 2925 & 4 & 14 \\
\hline Etridiazole & 5 & 15 & 12 & 23 & 18 & 146 & 81 & 1490 \\
\hline Vinclozolin & 29 & 740 & 1 & 1 & 69 & 4815 & 4 & 45 \\
\hline Triadimefon & 73 & 716 & 5 & 34 & 74 & 627 & 7 & 4 \\
\hline Ferbam & 19 & 1336 & 2 & 153 & 5 & 11 & 3 & 1 \\
\hline Fenarimol & 22 & 671 & 1 & 1 & 28 & 144 & 2 & 1 \\
\hline Triflumazole & 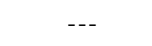 & --. & 1 & 4 & 2 & 3 & 9 & 118 \\
\hline Ziram & 4 & 78 & 1 & 35 & 1 & 18 & 2 & 4 \\
\hline
\end{tabular}


Table 3. Fungicide use for different types of disease control.

\begin{tabular}{|c|c|c|c|c|}
\hline \multirow[b]{3}{*}{ Fungicide/bactericide } & \multicolumn{4}{|c|}{ Active ingredient (\%) } \\
\hline & \multicolumn{2}{|c|}{ Field use } & \multicolumn{2}{|c|}{ Greenhouse use } \\
\hline & Foliar & Root & Foliar & Root \\
\hline Thiophanate methyl & $41.6^{2}$ & 7.6 & 19.4 & 31.4 \\
\hline Chlorothalonil & 81.3 & 2.3 & 16.0 & 0.4 \\
\hline Mancozeb & 82.5 & 0.8 & 16.6 & 0.1 \\
\hline Metalaxyl & 5.5 & 45.3 & 7.6 & 41.6 \\
\hline Captan & 16.0 & 1.4 & 3.6 & 79.0 \\
\hline Fosetyl al & 16.4 & 60.2 & 11.5 & 11.9 \\
\hline Copper & 93.3 & 0.1 & 6.2 & 0.4 \\
\hline Propiconazole & 95.5 & 0.8 & 3.7 & -- \\
\hline PCNB & 6.0 & 68.6 & 0.3 & 25.1 \\
\hline Triforine & 61.9 & --. & 37.9 & 0.2 \\
\hline Etridiazole & 5.7 & 13.1 & 7.5 & 73.7 \\
\hline Vinclozolin & 27.0 & 7.7 & 38.8 & 26.5 \\
\hline Triadimefon & 51.8 & 2.5 & 45.4 & 0.3 \\
\hline Ferbam & 89.0 & 10.2 & 0.7 & 0.1 \\
\hline Fenarimol & 82.2 & 0.1 & 17.6 & 0.1 \\
\hline Triflumizole & --- & 3.2 & 2.4 & 94.4 \\
\hline Ziram & 62.8 & 30.9 & 3.3 & 3.0 \\
\hline
\end{tabular}

${ }^{2}$ Calculated by amount active ingredient for different site/total amount active ingredient for each fungicide/bactericide. new products and services for the ornamentals industry as well as to evaluate the degree of knowledge, use, and efficacy of the full range of disease control methods currently available. Future research, extension, and allied industry efforts might use this type of information to serve the ornamentals industry more effectively.

This survey was conducted and data analyzed as detailed previously (Garber et al., 1996).

\section{Results and discussion}

Fungicide use patterns. The number of respondents reporting use of various fungicides/ bactericides is given in Table 1 in descending order of active ingredient, with at least $1 \%$ of the respondents reporting its use. Themost frequently used fungicidewas metalaxyl (Subdue) with atotal of $47 \%$ of respondents reporting its use. The next most commonly applied fungicides were thiophanate-methyl $(45 \%)$ and chlorothalonil (32\%). Fungicides (in addition to metalaxyl) used for control of pythiaceous fungi included fosetyl aluminum (27\%) and etridiazole (13\%), for atotal of $87 \%$ of the respondents using at least one fungicide product for control of pythiaceous fungi. About $22 \%$ of the respondents reported use of a copper compound and about $28 \%$ used some formulation of maneb/mancozeb. The balance between broad-spectrum and other fungicides was about equal when considering a narrow-spectrum fungicideis onethat gives good control of only one or two major groups of plant pathogens. The most significant factor influencing this balance was the use of fungicides specific for pythiaceous fungi ,which areconsidered anonbroad-spectrum group. In general, a preference for broad-spectrum products such as thiophanate methyl, chlorothalonil, copper, or mancozeb prevailed.

The volume of fungicide/bactericidediffered from the reported frequency, since use rates differ dramatically (Table 1). Highest-volume products of the total reported were thiophanate methyl at $470,926 \mathrm{lb}(214,058 \mathrm{~kg})(31 \%)$, chlorothalonil at $285,170 \mathrm{lb}(129,623 \mathrm{~kg})(19 \%)$, and mancozeb at $194,106 \mathrm{lb}(88,230 \mathrm{~kg})(13 \%)$. Metalaxyl, used at very low rates, accounted for only $102,150 \mathrm{lb}$ $(46,432 \mathrm{~kg})(7 \%)$ of the total volume of active ingredients reported, even though it was used by thehighest percentage of growers. Iprodione, captan, and fosetyl al each accounted for about $5 \%$ of the total volume of fungicides used. Respondents were asked to report use of each fungicide/bactericide according to treatment site and type of disease targeted for control (Table 2). In general, fewer respondents applied products for control of root diseases in the field than any other type. Greenhouse producers applied more fungicides for root disease control. This may be related to a greater ability to affect the root environment and to the generally higher crop value and production costs, which can bear this expense. While most fungicides are used appropriately, inconsistencies with the label and the potential benefits of the fungicide can be found. A significant number of respondents reported using etridiazole and metalaxyl for foliar disease control, which is inconsistent with label instructions and potential beneficial use. Educational efforts should continue to stress the need for consistency in fungicideuseaccording to labeled directions and known activity.

The percent of active ingredient for each chemical product used under various growing conditions is given in Table 3 . Some products (propiconazole, benomyl, and copper) are used al most exclusively for a single target such as foliar diseases in the field. One hundred percent of piperalic acid use was reported for foliar disease control in the greenhouse. Etridiazole was used mainly for root disease control in the greenhouse. About the same amount of metalaxyl was used for root disease control in the field as in the greenhouse (Tables 2 and 3). Thiophanate methyl was used primarily for foliar disease control in the field but for root disease control in the greenhouse. Finally, theproducts with themost broad spectrum were used in roughly equal amounts in the field and greenhouse for root and foliar diseases (e.g., thiophanate-methyl).

A summary of the fungicide use comparing greenhouse vs. field and for foliar disease vs. root disease use reveals that almost $54 \%$ of the active ingredient was applied to field-grown ornamentals for foliar diseases (Table 4). Use of fungicides in greenhouses was considerably less, 19\% being applied for foliar disease and $17 \%$ applied for root diseases. Thesmallest amount of activeingredient was applied to field-grown ornamentals for control of root diseases. More respondents used fungicides for foliar diseases (field and greenhouse) than for root disease control. The relatively low use rate (active ingredient) of metalaxyl, which is the most widely used fungicide, may account for all of this effect.

Patterns of fungicide use also differed by regions. Morecaptan was used in thenortheastern region (Table 5) than any other fungicide whereas thiophanate-methyl was the most widely used
Table 4. Total disease-control fungicide used for four categories of disease.

\begin{tabular}{lccccc}
\hline & \multicolumn{2}{c}{ Amount } & & \multicolumn{2}{c}{ Frequency } \\
\cline { 2 - 3 } \cline { 5 - 6 } Category & Active ingredient (lb) & $\%^{z}$ & & No. & $\%^{y}$ \\
\hline Field use & & & & \\
$\quad$ Foliar & 248048 & 53.8 & 1100 & 33.9 \\
$\quad$ Root & 47020 & 10.2 & & 442 & 13.6 \\
Greenhouse use & & & & \\
$\quad$ Foliar & 87647 & 19.0 & & 985 & 30.4 \\
$\quad$ Root & 78246 & 17.0 & 715 & 22.1 \\
Total & 460962 & 100.0 & 3242 & 100.0 \\
\hline
\end{tabular}

${ }^{z}$ Amount of active ingredient used in each category divided by total amount of active ingredient for all fungicides. ${ }^{y}$ Calculated as the total number of users in each category divided by total users of fungicide; some totals exceed number of respondents in survey due to use of more than one fungicide by some respondents. 
Table 5. Estimated fungicide use in the northeastern region.

\begin{tabular}{|c|c|c|c|c|}
\hline \multirow[b]{2}{*}{ Fungicides } & \multicolumn{2}{|c|}{ Respondents } & \multicolumn{2}{|c|}{ Amount (Ib) } \\
\hline & No. & $\%^{2}$ & Estimated total active ingredient ${ }^{y}$ & $\%$ \\
\hline Captan & 32 & 22 & 69705 & 41 \\
\hline Chlorothalonil & 33 & 23 & 20944 & 12 \\
\hline Thiophanate methyl & 42 & 29 & 16123 & 10 \\
\hline Fosetyl Al & 23 & 16 & 13717 & 8 \\
\hline Mancozeb & 39 & 27 & 10403 & 6 \\
\hline Metalaxyl & 58 & 41 & 7948 & 5 \\
\hline Vinclozolin & 13 & 9 & 6492 & 4 \\
\hline PCNB & 10 & 7 & 6438 & 4 \\
\hline Etridiazole & 17 & 12 & 3943 & 2 \\
\hline Copper & 17 & 12 & 1988 & 1 \\
\hline Iprodione & 16 & 11 & 1397 & 1 \\
\hline Fenarimol & 8 & 6 & 883 & 1 \\
\hline Triadimefon & 20 & 14 & 821 & $<1$ \\
\hline Ferbam & 8 & 6 & 353 & $<1$ \\
\hline Triforine & 10 & 7 & 262 & $<1$ \\
\hline Triflumizole & 2 & 1 & 304 & $<1$ \\
\hline Propiconazole & 5 & 3 & 105 & $<1$ \\
\hline Ziram & 1 & 1 & 27 & $<1$ \\
\hline Other $^{x}$ & 16 & 11 & 6892 & 4 \\
\hline Total & 370 & & 168663 & 100 \\
\hline
\end{tabular}

Determined by dividing number of users for each chemical by number of respondents from the respective region.

YUse for respondents expanded to total estimated use using USDA total sales for greenhouse/nursery industry; ratio of respondents sales to USDA sales used to estimate total use. xIncludes benomyl, dodemorph, phaltan, piperalic acid and sulfur.

fungicidein theother three regions. Metalaxyl was used by the greatest percentage of the growers in the northeastern and western regions, whereas thiophanate-methyl was used by the highest percentage of the growers in the southeastern (Table
6) and north-central (Table 7) regions. The greatest total estimated use of fungicide occurred in the southeastern region (Table 6). The lowest amount of fungicide use was reported in the northeastern region (Table5). The amount of captan used in the northeastern region (Table 5) and thiophanatemethyl used in the north-central region (Table 7) was more than three times that of any other fungicide. In the southeastern (Table 6) and western (Table 8 ) regions, the amount of fungicides used

Table 6. Estimated fungicide use in the southeastern region.

\begin{tabular}{|c|c|c|c|c|}
\hline \multirow[b]{2}{*}{ Fungicide } & \multicolumn{2}{|c|}{ Respondents } & \multicolumn{2}{|c|}{ Amount (lb) } \\
\hline & No. & $\%^{2}$ & Estimated total active ingredient ${ }^{y}$ & $\%$ \\
\hline Thiophanate methyl & 111 & 53 & 232297 & 30 \\
\hline Chlorothalonil & 82 & 39 & 175002 & 22 \\
\hline Mancozeb & 67 & 32 & 133017 & 17 \\
\hline Metalaxyl & 107 & 51 & 39967 & 5 \\
\hline Iprodione & 40 & 19 & 36400 & 5 \\
\hline Propiconazole & 29 & 14 & 32425 & 4 \\
\hline Fosetyl Al & 61 & 29 & 29085 & 4 \\
\hline Copper & 62 & 30 & 24210 & 3 \\
\hline Etridiazole & 22 & 11 & 22931 & 3 \\
\hline Triforine & 24 & 11 & 17968 & 2 \\
\hline PCNB & 20 & 10 & 15177 & 2 \\
\hline Captan & 49 & 23 & 7061 & 1 \\
\hline Propamocarb & 3 & 1 & 4436 & 1 \\
\hline Ferbam & 12 & 6 & 2177 & $<1$ \\
\hline Triadimefon & 32 & 15 & 1565 & $<1$ \\
\hline Vinclozolin & 17 & 8 & 1273 & $<1$ \\
\hline Triflumizole & 4 & 2 & 200 & $<1$ \\
\hline Ziram & 1 & $<1$ & 78 & $<1$ \\
\hline Fenarimol & 5 & 2 & 18 & $<1$ \\
\hline Other $^{x}$ & 15 & 7 & 2886 & $<1$ \\
\hline Total & 763 & & 77822 & 100 \\
\hline
\end{tabular}

${ }^{2}$ Determined by dividing number of users for each chemical by number of respondents from the respective region.

y Use for respondents expanded to total estimated use using USDA total sales for greenhouse/nursery industry; ratio of respondents sales to USDA sales used to estimate total use. xIncludes Agribrom, AMCL, Benomyl, Dinocap, Dodemorph, piperalic acid, and Steptomycin. 
Table 7. Estimated fungicide use in the north-central region.

\begin{tabular}{|c|c|c|c|c|}
\hline \multirow[b]{2}{*}{ Fungicide } & \multicolumn{2}{|c|}{ Respondents } & \multicolumn{2}{|c|}{ Amount (lb) } \\
\hline & No. & $\%^{2}$ & Estimated total active ingredient ${ }^{y}$ & $\%$ \\
\hline Thiophanate methyl & 98 & 46 & 129104 & 54 \\
\hline Chlorothalonil & 64 & 30 & 38998 & 16 \\
\hline Metalaxyl & 81 & 38 & 21805 & 9 \\
\hline Iprodione & 44 & 21 & 15190 & 6 \\
\hline Mancozeb & 47 & 22 & 7009 & 3 \\
\hline Vinclozolin & 26 & 12 & 5831 & 2 \\
\hline Fosetyl Al & 43 & 20 & 3581 & 1 \\
\hline Propiconazole & 16 & 7 & 3400 & 1 \\
\hline Captan & 52 & 24 & 2793 & 1 \\
\hline PCNB & 29 & 14 & 2534 & 1 \\
\hline Copper & 28 & 13 & 2223 & 1 \\
\hline Etridiazole & 40 & 19 & 1818 & 1 \\
\hline Ferbam & 6 & 3 & 1521 & 1 \\
\hline Triadimefon & 39 & 18 & 958 & 1 \\
\hline Triforine & 20 & 9 & 674 & 1 \\
\hline Fenarimol & 11 & 5 & 453 & $<1$ \\
\hline Triflumizole & 3 & 1 & 112 & $<1$ \\
\hline Other ${ }^{x}$ & 14 & 7 & 902 & 1 \\
\hline Total & 661 & & 238905 & 100 \\
\hline
\end{tabular}

zDetermined by dividing number of users for each chemical by number of respondents from the respective region.

y Use for respondents expanded to total estimated use using USDA total sales for greenhouse/nursery industry; ratio of respondent sales to USDA sales used to estimate total use. xIncludes benomyl, dodemorph, dodine, myclobutranil, oxycarbofuran, and piperalic acid.

was more evenly distributed among several fungicides. The percent of estimated active ingredient for captan in the northeastern region (Table 5) was $41 \%$, whereas it represents only $1 \%$ in the southeastern (Table 6) and north-central (Table 7) regions and $2 \%$ in the western (Table 8 ) regions. Chlorothalonil was the second most heavily used fungicide in all four regions; thiophanate-methyl was the most heavily used fungicide in the southeastern, north-central, and western regions.

Alternatives to chemical disease control. The most-frequently used alternatives to diseasecontrol chemical s weremonitoring/scouting $(92.8 \%)$, inspection of incoming stock (90.6\%), sanitation $(89.1 \%)$, irrigation delivery/timing (82.6\%), and resistant cultivars (79.5\%) (Table 9). Fertility management $(71.3 \%)$, crop rotation $(60.7 \%)$, roguing $(60.1 \%)$, and isolation $(54.7 \%)$ also were used by at least $50 \%$ of the respondents. Media sterilization (48.9\%), greenhouse relative humidity control (48\%), and culture indexed starter

Table 8. Estimated fungicide use in the western region.

\begin{tabular}{|c|c|c|c|c|}
\hline \multirow[b]{2}{*}{ Fungicide } & \multicolumn{2}{|c|}{ Respondents } & \multicolumn{2}{|c|}{ Amount (Ib) } \\
\hline & No. & $\%^{2}$ & Estimated total active ingredient ${ }^{y}$ & $\%$ \\
\hline Thiophanate methyl & 65 & 49 & 93401 & 27 \\
\hline Chlorothalonil & 46 & 34 & 50226 & 14 \\
\hline Mancozeb & 44 & 33 & 43678 & 13 \\
\hline Copper & 50 & 37 & 38047 & 11 \\
\hline Metalaxyl & 84 & 63 & 32431 & 9 \\
\hline Fosetyl Al & 60 & 45 & 27979 & 8 \\
\hline Iprodione & 65 & 49 & 17133 & 5 \\
\hline Triforine & 24 & 18 & 10509 & 3 \\
\hline PCNB & 25 & 19 & 10329 & 3 \\
\hline Captan & 26 & 19 & 6756 & 2 \\
\hline Vinclozolin & 31 & 23 & 4284 & 1 \\
\hline Fenarimol & 23 & 17 & 1559 & 1 \\
\hline Triadimefon & 42 & 31 & 1370 & 1 \\
\hline Ferbam & 2 & 1 & 619 & $<1$ \\
\hline Ziram & 6 & 4 & 413 & $<1$ \\
\hline Propiconazole & 9 & 7 & 141 & $<1$ \\
\hline Triflumizole & 5 & 4 & 76 & $<1$ \\
\hline Etridiazole & 11 & 8 & 151 & $<1$ \\
\hline Other $^{x}$ & 19 & 14 & 8684 & 2 \\
\hline Total & 637 & & 347785 & 100 \\
\hline
\end{tabular}

zDetermined by dividing number of users for each chemical by number of respondents from the respective region.

y Use for respondents expanded to total estimated use using USDA total sales for greenhouse/nursery industry; ratio of respondent sales to USDA sales used to estimate total use xIncludes Agribrom, AMCL, benomyl, dodemorph, myclobutranil, oxycarbofuran, piperalic acid, and sulfur. 
Table 9. Experience with and frequency of use of disease control alternatives in the United States greenhouse and nursery industry.

\begin{tabular}{|c|c|c|c|c|c|}
\hline \multirow[b]{2}{*}{ Alternative control } & \multirow[b]{2}{*}{ Respondents } & \multirow[b]{2}{*}{ Used } & \multicolumn{3}{|c|}{ Experience (\% response) } \\
\hline & & & Not effective & Effective ${ }^{z}$ & Effective but impractical \\
\hline Fertility management & 460 & 71.3 & 3.9 & 95.8 & 0.2 \\
\hline Irrigation delivery/timing & 536 & 82.6 & 2.1 & 96.1 & 1.9 \\
\hline Pathogen (cultured) indexed starter plants & 199 & 31.8 & 4.5 & 93.4 & 2.0 \\
\hline Greenhouse relative humidity control & 299 & 48.0 & 2.7 & 93.9 & 3.3 \\
\hline Resistant cultivars & 519 & 79.5 & 1.7 & 95.0 & 3.3 \\
\hline Roguing & 376 & 60.1 & 3.2 & 93.7 & 3.2 \\
\hline Media sterilization & 314 & 48.9 & 4.1 & 87.9 & 8.0 \\
\hline Crop rotation & 393 & 60.7 & 6.9 & 87.0 & 6.1 \\
\hline Sanitation & 589 & 89.1 & 0.7 & 97.8 & 1.5 \\
\hline Isolation of incoming stock & 346 & 54.7 & 10.1 & 73.5 & 16.5 \\
\hline Monitoring/scouting & 605 & 92.8 & 2.1 & 96.5 & 1.3 \\
\hline Inspection of incoming stock & 595 & 90.6 & 3.2 & 95.1 & 1.7 \\
\hline
\end{tabular}

${ }^{2}$ Combined response for somewhat effective and very effective.

plants (31.8\%) also were reported but less commonly used. The general experience with each method was very good, and all methods were reported as effective. Isolation of starter material was reported as effective (73.5\%), but asignificant percentage of respondents reported it as effective but impractical (16.5\%). It is apparent that if an alternative method is used, it is very successful (Table 9). Additional alternatives listed by the respondents for foliar drying and reduction of relative humidity were foliar rinse with a surfactant following watering, horizontal air fans, plant spacing, and aeration. Spot treatment, $\mathrm{pH}$ management, pruning, biological control, and control of run-off to prevent standing water also were mentioned by at least one respondent. The use of hydrogenperoxide and chlorination of water also were reported as alternatives to chemical disease control methods, despite the fact that these are chemical products.

Regional use of alternative methods showed a similar response for most methods. The most obvious differences in use were in greenhouse relative humidity management and media sterilization, which were used significantly more in the western region (66.1\% and $60.2 \%$, respectively) than in the other regions $(41.3 \%$ to $47 \%$ and $40.8 \% \%$ to $52.1 \%$, respectively). Fertility man- agement was used a little more frequently in the north-central region than in the other regions. Respondents in the northeastern region reported nearly all methods were effective or very effective ,whereas at least $10 \%$ of the respondents in the southeastern and the north-central regions reported mediasterilization and isolation were effective but impractical (Table 10). In the western region, morethan $21 \%$ reported that isolation was effective but impractical, and $10 \%$ reported crop rotation as effective but impractical.

The effect of firm size on frequency of use of alternatives to disease control chemicals varied. Frequency of use of fertilization management, irri-

Table 10. Experience with disease control alternatives in different regions.

\begin{tabular}{|c|c|c|c|c|c|c|c|c|c|c|c|c|}
\hline \multirow[b]{3}{*}{ Controlalternative } & \multicolumn{12}{|c|}{ Experience (\% response) } \\
\hline & \multicolumn{4}{|c|}{ Not effective } & \multicolumn{4}{|c|}{ Effective $^{z}$} & \multicolumn{4}{|c|}{ Effective but impractical } \\
\hline & $\mathrm{I}^{\mathrm{y}}$ & II & III & IV & $\mathrm{I}$ & II & III & IV & 1 & II & III & IV \\
\hline \multicolumn{13}{|l|}{ Fertility } \\
\hline management & 4.1 & 4.7 & 3.3 & 3.8 & 94.9 & 95.3 & 96.7 & 96.3 & 1.0 & --- & --- & -- \\
\hline Irrigation delivery/ & & & & & & & & & & & & \\
\hline $\begin{array}{l}\text { timing } \\
\text { Pathogen (cultured) } \\
\text { indexed starter }\end{array}$ & 4.4 & 1.3 & 1.3 & 1.9 & 94.7 & 97.4 & 96.2 & 96.3 & 0.9 & 1.3 & 2.6 & 1.9 \\
\hline plants & 6.8 & 2.1 & 3.1 & 7.9 & 93.2 & 93.7 & 95.3 & 92.1 & -- & 4.2 & 1.5 & -- \\
\hline Greenhouse relative & & & & & & & & & & & & \\
\hline $\begin{array}{l}\text { humidity control } \\
\text { Resistant cultivars }\end{array}$ & 18 & $\begin{array}{l}5.8 \\
0.7\end{array}$ & 1.2 & $\begin{array}{l}3.8 \\
2.3\end{array}$ & $\begin{array}{l}95.3 \\
97.3\end{array}$ & 91.3 & $\begin{array}{l}95.3 \\
93.4\end{array}$ & $\begin{array}{l}93.5 \\
920\end{array}$ & $\begin{array}{l}4.8 \\
0.9\end{array}$ & $\begin{array}{l}2.9 \\
27\end{array}$ & $\begin{array}{l}3.5 \\
42\end{array}$ & $\begin{array}{l}2.6 \\
57\end{array}$ \\
\hline Roguing & 1.2 & 2.0 & 3.7 & 6.4 & 93.9 & 95.1 & 95.5 & 89.8 & 4.9 & 3.0 & 0.9 & 3.8 \\
\hline Media sterilization & 6.8 & --- & --- & 10.8 & 87.6 & 89.4 & 90.1 & 83.7 & 5.5 & 10.6 & 10.0 & 5.4 \\
\hline Crop rotation & 6.7 & 7.5 & 5.7 & 8.5 & 92.1 & 85.1 & 87.8 & 81.7 & 1.1 & 7.5 & 6.5 & 9.9 \\
\hline $\begin{array}{l}\text { Sanitation } \\
\text { Isolation of }\end{array}$ & -- & 0.6 & 0.5 & 1.8 & 99.2 & 96.9 & 97.8 & 97.3 & 0.8 & 2.4 & 1.6 & 0.9 \\
\hline incoming stock & 9.1 & 10.7 & 7.9 & 14.1 & 83.3 & 71.9 & 75.3 & 64.8 & 7.6 & 17.5 & 16.8 & 21.1 \\
\hline Monitoring/ & & & & & & & & & & & & \\
\hline scouting & 1.6 & 1.8 & 1.6 & 4.5 & 97.7 & 95.2 & 97.9 & 95.6 & 0.8 & 3.0 & 0.5 & -- \\
\hline $\begin{array}{l}\text { Inspection of } \\
\text { incoming stock }\end{array}$ & 4.7 & 1.8 & 3.2 & 2.8 & 94.5 & 97.0 & 95.1 & 93.5 & 0.8 & 1.2 & 1.6 & 3.7 \\
\hline
\end{tabular}

${ }^{y}$ Region of the country as defined in materials and methods: I, northeastern; II, southeastern; III, north-cntral; and IV, western. 
gation management, culture-indexed plants, humidity control, roguing, and isolation increased as firm size increased. In contrast, use of resistant cultivars, rotation, sanitation, scouting and monitoring was about the same for all size firms. Use of media sterilization increased from small to medium firms but was lower for large than medium firms. This may be due to an increased use of prepared, bagged potting media by the largest firms. Experience with alternatives generally was not affected by firm size. As firm size increased, there was an increase in frequency of responses listing the following alternatives as effective but impractical: resistant cultivars, media sterilization, and isolation. Large firms were more likely to report the alternative methods as effective but impractical.

The extensiveuse of alternativediseasecontrol demonstrates a willingness and perceived need by the greenhouse and nursery industry to use alternatives to chemical products. Most alternatives were viewed with a moderate degree of enthusiasm and have met with at least some success. The least used alternative is culture indexing which is the backbone strategy for control of Xanthomonas blight on geranium and several serious viral diseases. Dueto limited applications on other major ornamentals, the technique has not been used fully. Many plants are produced using tissue culture methods, but their pathogen-free status is not a primary concern and is not rigorously sought by either the ornamental grower or the tissue-culture specialist. Application of this alternative should be expanded if we are to realize optimal disease-control strategies.

More than $90 \%$ of the respondents used resistant cultivars of their ornamental plants. The industry may need added emphasis in this area as we encounter increased regulations, decreased chemical pesticide availability, and increased environmental awareness. This is critical for theplant producer and the consumer, who also needs a resistant plant to eliminate the future need for fungicides in the landscape. This would also be a good marketing tool.

The best-used alternatives, scouting and monitoring, aretwo components of the samemethodology and have perhaps cometo diseasecontrol viainsect and mitecontrol. Mediasterilization may havelost importance in the past 10 years due to the widespread availability of packaged potting media ,which are relatively free of plant pathogens.

The availability of chemical bactericide and fungicide products changes rapidly as products are lost and others are introduced. Since Du Pont removed ornamentals from the Benlate label in 1991 , the sales of thiophanate-methyl for use on ornamentals and turf increased 200\% (1991-94). Despite the changes, it is obvious that chemicals are still an integral part of most disease-control programs. It is important to notethat most growers are starting to address disease control with an integrated approach, and the days of spraying on a calendar basis are limited for most ornamental producers.

\section{Literature Cited}

Barnes, L.W. 1994. Consider IPM for disease control. Greenhouse Manager 12(11):88-89.

Barnes, L.W. 1993. Knowledge and integrated control can help avoid botrytis outbreaks. Greenhouse Manager 12(8):105.

Bartok, Jr., J.W. 1990. Lower humidity hinders disease. GreenhouseManager 9(5):169-170, 172, 174.

Blaine, K. 1993. Palm Beach nurseries in uproar-Urban service area laws threaten industry's stability. Ornamental Outlook 2(7):10-11.

Cuny, H. 1995. Engineer the environment-How environmental control helps plants and hinders pathogens. Greenhouse Mgt. \& Production 13(12):30-32, 38-39.

Garber, M.P., W.G. Hudson, J.G. Norcini, R.K. Jones, A.R. Chase, and K. Bondari. 1996. Pest management in the United States greenhouse and nursery industry: I. Trends in chemical and nonchemical control. HortTechnology 6:192-198.
Horst, R.K., S.O. Kawamoto, and L.L. Rotter. 1992. Effect of sodium bicarbonate and oils on the control of powdery mildew and black spot of roses. Plant Dis. 76:247-251.

Kelly, M.K. 1994. Thewell-ventilated greenhouse. GrowerTalks 57(12):54-57.

Klassen, P. 1992. Pesticide use under fire. Greenhouse Grower 10(9):72-73.

Lawson, R.H. 1994. Silicon reduces Pythium losses. Greenhouse Manager 13(1):81-82.

Murashige, T. 1974. Plant propagation through tissue culture. Annu. Rev. Plant Physiol. 25:135166.

Onofrey, D. 1994. Environmental controls leave fungi dry. Greenhouse Grower 12(13):32-33, 36.

Pardo, R. 1995. Chemicals: Friends or foes? Landscape and Nursery Dig. 29(1):50-52.

Pommer, E.-H, and G. Lorenz. 1982. Resistance of Botrytis cinerea Pers. to dicarboximide fungicides-A literature review. Crop Protection 1(2):221-230.

Priapi, V.M. 1993. Clean pays off! Nursery Manager (June):58, 60, 62.

Roberts, D.L. 1994. Metalaxyl-resistant Pythium sp.: You can still fight it. Greenhouse Grower 12(8):59, 62.

SAS Institute. 1989. SAS/STAT user's guide, version 6. 4th ed. SAS Inst., Cary, N.C.

Steward, V.B. 1993. Superior oil sprays-A safe winter-only pesticide can now be sprayed during the growing season. Fine Gardening 30:68-69.

Whitten, M. 1994. Profits could sink with no alternative to methyl bromide. Greenhouse Manager 12(12):90, 92-95.<smiles>CC1=C(C(=O)Nc2ccccc2)SCCO1</smiles><smiles>O=[N+]([O-])c1c(Cl)c(Cl)c(Cl)c(Cl)c1Cl</smiles><smiles>CC1=C(C(=O)Nc2ccccc2)SCCO1</smiles><smiles>O=[N+]([O-])c1c(Cl)c(Cl)c(Cl)c(Cl)c1Cl</smiles><smiles>O=C1C2CC=CCC2C(=O)N1SC(Cl)(Cl)Cl</smiles><smiles>O=C1C2CC=CCC2C(=O)N1SC(Cl)(Cl)Cl</smiles><smiles>CC1=C(C(=O)Nc2ccccc2)SCCO1</smiles> 